\title{
Transplantation of purified islet cells in diabetic BB rats
}

\author{
D.Pipeleers ${ }^{1}$, M.Pipeleers-Marichal ${ }^{2}$, H.Markholst ${ }^{3}$, A. Hoorens ${ }^{2}$ and G. Klöppel ${ }^{2}$ \\ 1 Department of Metabolism and Endocrinology, ${ }^{2}$ Department of Pathology, Vrije Universiteit Brussel, Brussels, Belgium and \\ ${ }^{3}$ Hagedorn Research Laboratory, Gentofte, Denmark
}

\begin{abstract}
Summary. The ability to prepare purified islet Beta-cell aggregates was used to examine the survival of this cell type after allotransplantation in diabetic BB rats. The aggregates were intraportally implanted in numbers that were previously found to correct a streptozotocin-induced diabetic state in syngeneic or allogeneic Brown Norway recipients. When the grafts were prepared from RT $1^{\text {ul }}$ donors, which shared the MHC-class I antigen with the BB recipients (RT1 ${ }^{w u}$ ), their implant sites became diffusely infiltrated by inflammatory cells and their metabolic function was completely lost within 5 weeks. MHC-class I incompatible islet Beta-cell allografts $\left(R T 1^{n / n}\right)$ exhibited a longer survival, in particular when combined with other islet endocrine cells and/or when covered by a 5-week cyclosporin treatment. In the latter combination, 10 of $12 \mathrm{BB}$ rat recipients remained normoglycaemic over the 10 -week observation period, their
\end{abstract}

liver implants presenting a comparable insulin reserve and similarly discrete mononuclear cell infiltration as streptozotocin-diabetic Brown Norway rats receiving this treatment. However, administration of cyclosporin to diabetic BB rats was associated with a morbidity that was not observed in drug-treated streptozotocin-diabetic Brown Norway animals or in untreated diabetic BB rats. It is concluded that MHC-incompatible islet Beta cells can induce a long-term normalization in diabetic BB rats provided that they are implanted under conditions which allow allograft acceptance. The standardized preparation of purified islet Beta-cell grafts can help assessing the conditions for successful transplantations in diabetes with an autoimmune origin.

Key words: Transplantation, diabetes mellitus, islet cells, $\mathrm{BB}$ rats, cyclosporin.
Purified endocrine rat islet cells survive transfer across a major histocompatibility barrier markedly better than unpurified islet preparations [1]. As a result of this property, allografts of purified islet cell aggregates can maintain a long-term normoglycaemia in animals with chemically-induced diabetes [1]. The implants elicit a mononuclear cell infiltration but the immune response is mild and delayed [1] and hence suppressable by short-term cyclosporin treatment [2]. In addition to their lower immunogenicity, purified islet cell aggregates offer the advantage of a standarized preparation, the size and cellular composition of which can be precisely determined in vitro [3]. For these reasons, they appear more appropriate than previously used preparations in assessing the applicability of islet cell transplantation in autoimmune diabetes. In this form of the disease, destructive processes against pancreatic Beta cells can recur as soon as a new pool of islet Beta cells is presented to the immune system $[4,5]$. The reappearance and severity of the autoimmune phenomena may, however, depend on the number of grafted Beta cells, on their immunogenicity as well as on the simultaneous transfer of other cell types. Each of these variables can be tested separately with in vitro constructed islet cell implants of selected size and cellular composition. In the present study, we have examined whether allografted islet Beta cells can survive after implantation in diabetic BB rats, which are known to have developed autoimmune reactions against their own pancreatic Beta cells [6]. The grafts were composed of a fixed number of islet Beta cells that were purified from rat strains with or without disparity in MHCclass I antigens.

\section{Materials and methods}

\section{Preparation of donor tissue}

Donor tissue was prepared from adult male rats $(200-300 \mathrm{~g}$ body weight) of the inbred R/A (RT1- $p^{\mathrm{u} / 1}$, identical in defined histocompatibility antigens to the RP strain, formerly R1) strain and of the inbred Brown Norway (BN) (RT1-n ${ }^{\mathrm{n} / 1 / 2}$ ) strain (colonies of Heverlee, Belgium, [3]). We recently described the methods used for the isolation of islets and the preparation of islet cell aggregates composed of 
either purified islet Beta cells or of mixed endocrine islet cells [3]. The cell aggregates were cultured for 4 days in RPMI-1640 containing $8.3 \mathrm{mmol} / \mathrm{l}$ glucose, $25 \mu \mathrm{mol} / \mathrm{l}$ isobutyl methyl xanthine, $25 \mu \mathrm{mol} / \mathrm{l}$ dibutyryl cyclic AMP, $2 \mathrm{mmol} / 1$ L-glutamine, $10 \%$ (volume/volume) heat-inactivated fetal calf serum supplemented with penicillin $(0.1 \mathrm{mg} / \mathrm{ml})$ and streptomycin $(0.1 \mathrm{mg} / \mathrm{ml})$. After culture they were filtered through a percoll layer of density 1.04 in order to remove cell debris and then resuspended in albumin-free medium for transplantation [1].

\section{Recipients}

Donor tissue was implanted by intraportal injection in diabetic male BB/Hagedorn rats $\left(\right.$ RT $\left.^{\mathrm{u} / \mathrm{u}}\right)$. The animals were born at the Hagedorn Institute and shipped to Brussels after 60 days of age. Clinical onset of diabetes occurred between the ages of 60 and 120 days. All animals were treated with insulin (zinc protamine insulin, a gift of Nordisk, Gentofte, Denmark) from the day of clinical onset until the day of transplantation, 4 to 20 weeks later; insulin administration was discontinued after transplantation. Recipients were kept in metabolic cages to measure weekly urine volumes over $24 \mathrm{~h}$. Urine volume and body weight were measured weekly, plasma glucose levels monthly. A state of normalization was defined by a daily urine volume under $16 \mathrm{ml}$ and plasma glucose levels under $11 \mathrm{mmol} / 1$. For each experimental group, the number of normalized recipients was taken as an index for the graft survival at a particular time after implantation [1].

Three groups of transplanted rats and one group of diabetic control rats were treated with cyclosporin for 5 weeks. The drug (donated by Sandoz, Basel, Switzerland) was solubilized in olive oil $(10 \mathrm{mg} / \mathrm{ml})$ and administered by gavage. One dose of $10 \mathrm{mg} / \mathrm{kg}$ was given $16 \mathrm{~h}$ before transplantation; during subsequent days, the animals received one daily dose of $5 \mathrm{mg} / \mathrm{kg}$. Previous experiments had shown that the administration of olive oil alone did not influence graft survival [2]. Cyclosporin levels in plasma were determined using the Sandoz radioimmunoassay kit [7].

\section{Analysis of liver and pancreas}

Liver and pancreas of recipients and controls were examined 10 weeks after transplantation, or earlier in the case of spontaneous death. Fragments were taken for histology and the remaining tissue was extracted for the insulin assay. A detailed description of the methodology has been given previously [1]. The histologic examination was conducted on $5 \mu \mathrm{m}$ thick sections which were stained with haematoxylin-eosin. Sections with endocrine tissue were im-

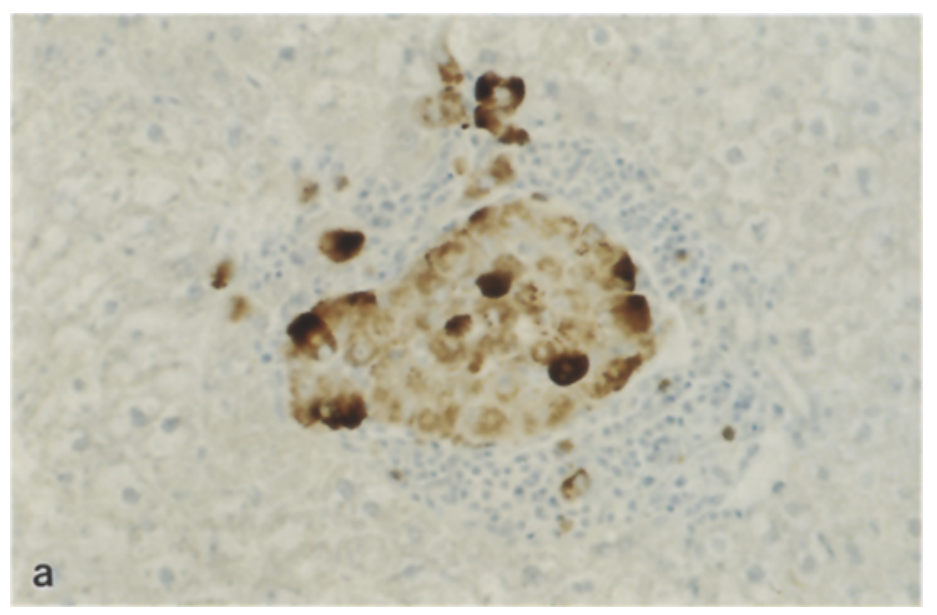

Fig. 1a,b. Light microscopy of intraportal implants consisting of $\mathrm{RT} 1^{\mathrm{u} / \mathrm{l}}$ purified Beta cells. After reversal to the diabetic state, several graft sites were still identified as aggregates containing insulin-positive cells and surrounded by a dense mononuclear infiltrate (a im-
Table 1. Survival of purified islet cell grafts $\left(\mathrm{RT} 1^{\mathrm{u} / \mathrm{I}}\right)$ in diabetic BB recipients $\left(\mathrm{RT}^{\mathrm{u} / \mathrm{u}}\right)$

\begin{tabular}{llllllll}
\hline \multirow{2}{*}{ Graft } & & \multicolumn{7}{c}{ Number of recipients } \\
\cline { 3 - 7 } & & Total & \multicolumn{5}{l}{ With surviving grafts } \\
\hline Post-transplant week & & & 1 & 2 & 3 & 5 & 10 \\
Aggregates purified & no Cy & 9 & 9 & 5 & 3 & 1 & 0 \\
Islet Beta cells & $\mathrm{Cy}$ & $7^{\mathrm{a}}$ & 7 & 5 & 1 & 0 & - \\
Aggregates purified & no Cy & 5 & 5 & 2 & 1 & 1 & 0 \\
Islet endocrine cells & & & & & & & \\
\hline
\end{tabular}

a not included is one recipient that died in oliguria at week 3 . Cy: Cyclosporin A $5 \mathrm{mg} \cdot \mathrm{kg}^{-1}$. $\mathrm{day}^{-1}$ for 5 weeks

munocytochemically stained for insulin and glucagon. In animals which had died spontaneously, tissue from the heart, lung and kidney was also histologically examined.

\section{Results}

Metabolic capacity of $R T 1^{\mathrm{n} / \mathrm{n}}$ donor tissue

Aggregates of islet Beta cells isolated from $\mathrm{BN}$ rats $\left(\mathrm{RT}^{\mathrm{n} / \mathrm{n}}\right)$ corrected, within 3 days, daily urine volume and $4 \mathrm{~h}$ fasting plasma glucose levels in streptozotocin-diabetic $\mathrm{BN}$ rats (data not shown). The grafts were the same size (100-200 $\mu \mathrm{m}$ in diameter), cell number (a total of $10^{6}$ cells) and cellular composition (more than $95 \%$ islet Beta cells) as those prepared from RA rats $\left(\mathrm{RT} 1^{\mathrm{Li} /}\right)$ [3]. A mixture of $10^{6}$ islet Beta cells with $8.10^{5}$ islet endocrine non-Beta cells induced the same rapid normalization when isografted in diabetic $\mathrm{BN}$ rats (data not shown). Both groups of recipients remained normal for over 20 weeks.

\section{Survival of $\left(R T 1^{\mathrm{u} / \mathrm{l}}\right)$ Beta cells in diabetic $\left(R T 1^{\mathrm{u} / \mathrm{u}}\right) B B$ rats}

Intraportal transplantation of (RT1 $\left.1^{\mathrm{w} / 1}\right)$ Beta cell aggregates in diabetic $\mathrm{BB}$ rats corrected the diabetic state within 3 days (Table 1). Without any insulin treatment, all recipients remained oliguric for at least 1 week. However,

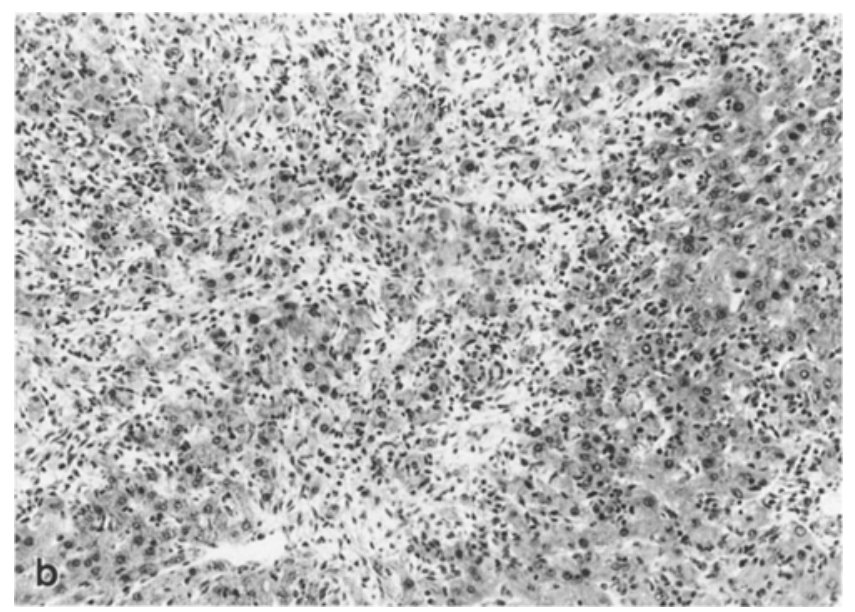

munoperoxidase stain for insulin, $\times 286$ ). When the recipient $\mathrm{BB}$ rat had been treated with cyclosporin, the liver often showed focal intralobular necrosis and dense inflammatory infiltrates (b HES, $\times 86$ ) 
all animals reversed to a diabetic state during the following 5 weeks (Table 1). One to two weeks after reversal, the liver content in insulin was low $(<1 \mu \mathrm{g}$ per organ), but sites of graft implantation were still recognizable from the presence of a few insulin-containing cells surrounded by mononuclear cell infiltrations (Fig. 1 a).

Administration of cyclosporin did not prolong the metabolic effects of the islet Beta cell grafts (Table 1). During the treatment period, one animal died in oliguria. Extraction of the livers, one to two weeks after reversal, indicated a low insulin content $(<1 \mu \mathrm{g}$ per organ). Several graft implantation sites were still histologically recognized as foci of mononuclear cells. Most livers showed spotty necrosis and diffuse sinusoidal infiltrations with mononuclear cells, suggestive of hepatitis (Fig. 1 b).

Mixtures of endocrine islet cells were also capable of normalizing the tested metabolic parameters for at least one week, but in none of the recipients was this effect long-lasting. By the 10th post-transplantation week, all animals were again diabetic (Table 1).

\section{Survival of $\left(R T 1^{\mathrm{n} / \mathrm{n}}\right)$ Beta cells in diabetic $\left(R T 1^{\mathrm{u} / 1}\right) B B$ rats}

Implantation of $\left(\mathrm{RT}^{\mathrm{n} / \mathrm{n}}\right)$ Beta cell aggregates corrected the diabetic state in all $\mathrm{BB}$ recipients (Table 2). Three weeks later, seven out of ten recipients were still normoglycaemic. However, at the end of the 10 th post-transplantation week, only three animals presented the signs of a surviving graft. Mixing the donor Beta cells with other endocrine islet cells did not prevent reversal to a diabetic state but restricted this phenomenon to the first three post-transplantation weeks (Table 2 ). With $\mathrm{RT} 1^{\mathrm{n} / \mathrm{n}}$ allografts, more recipients remained normalized up to week 10 (Table 2) than with RT1 ${ }^{\text {ull }}$ allografts (Table 1 ).

Analysis of liver tissue illustrated a longer survival of the RT1 ${ }^{\mathrm{n} / \mathrm{n}}$ donor tissue than of the RT1 ${ }^{\mathrm{u} / 1}$ implants:

In animals which reversed to a diabetic state within 2 to 5 weeks, the liver still contained donor Beta cells as evidenced by immunoassay of tissue extracts and by immunocytochemistry of tissue sections; the hepatic insulin content was markedly higher $\left(2\right.$ to $5 \mu \mathrm{g}$ ) than that in RT ${ }^{\text {u/l }}$ recipients shortly after reversal $(<1 \mu \mathrm{g})$.

In recipients which had maintained a normalized state for 10 weeks, the mean liver content in insulin was comparable to that in normalized streptozotocin-diabetic rats (Table 3, [2]). On the other hand, their pancreatic insulin

Table 2. Survival of purified islet cell grafts $\left(R T 1^{\mathrm{a} / \mathrm{n}}\right)$ in diabetic BB recipients $\left(\mathbf{R T} 1^{\mathrm{u} / \mathrm{u}}\right)$

\begin{tabular}{llrrrrrr}
\hline Graft & & \multicolumn{5}{c}{ Number of recipients } \\
\cline { 3 - 8 } & & Total & \multicolumn{4}{c}{ With surviving grafts } \\
\hline Post-transplant week & & & 1 & 2 & 3 & 5 & 10 \\
Aggregates purified & no Cy & 10 & 10 & 8 & 7 & 6 & 3 \\
Islet Beta cells & Cy & $7^{\text {a }}$ & 7 & 7 & 7 & 7 & 5 \\
Aggregates purified & no Cy & 12 & 12 & 10 & 6 & 6 & 5 \\
Endocrine islet cells & Cy & $5^{\text {b }}$ & 5 & 5 & 5 & 5 & 5 \\
\hline
\end{tabular}

not included are the ${ }^{\mathrm{a}} 4$ and ${ }^{\mathrm{b}} 2$ recipients that died in oliguria between weeks 3 and 10 . Cy: cyclosporin A $5 \mathrm{mg} \cdot \mathrm{kg}^{-1} \cdot$ day $^{-1}$ for 5 weeks
Table 3. Organ insulin content in oliguric BB rats (RT1 $\left.{ }^{\mathrm{u} / u}\right) 10$ weeks following transplantation of purified islet cells (RT1 ${ }^{n / n}$ )

\begin{tabular}{llll}
\hline Graft & & \multicolumn{2}{l}{ Insulin content } \\
\cline { 3 - 4 } & & Liver $\quad$ Pancreas \\
\hline Aggregates purified & no Cy & $(3)$ & $\mu$ gg/organ \\
Endocrine islet cells & Cy & $(4)$ & $13.8 \pm 4.4<1$ \\
\hline
\end{tabular}

Cy: cyclosporin A $5 \mathrm{mg} \cdot \mathrm{kg}^{-1} \cdot \mathrm{day}^{-1}$ for 5 weeks

content was markedly lower than in the streptozotocin transplants (Table 3, [2]). The liver tissue presented insulin-positive cell aggregates, one third of which was free of mononuclear cell infiltration, one third was peripherally infiltrated and one third diffusely (Fig. 2). The Beta cells varied in their individual intensity of insulin staining (Fig. 2).

\section{Effect of cyclosporin on the survival of $\left(R T 1^{\mathrm{n} / \mathrm{n}}\right)$ Beta cells in diabetic $\left(R T 1^{\mathrm{u} / \mathrm{u}}\right) \mathrm{BB}$ rats}

Diabetic BB rats in which implantation of (RT1 $\left.{ }^{\text {nin }}\right)$ purified islet cells was combined with cyclosporin treatment $\left(5 \mathrm{mg} \cdot \mathrm{kg}^{-1} \cdot\right.$ day $^{-1}$ orally) also normalized within the first 3 days following transplantation (Table 2). They reversed, however, markedly less frequently than untreated recipients, even after ceasing the treatment on post-transplantation day 35 (Table 2). Over the 10 -week observation period, reversal was noticed in only 2 out of 11 recipients of purified islet Beta cells, and in none of the seven recipients of purified mixed islet endocrine cells (Table 2). However, 6 of the 18 cyclosporin-treated animals died in an oliguric state, two during the last 2 weeks of cyclosporin administration and four shortly after discontinuation of the drug.

Microscopically, no difference was noted in the intraportal grafts of killed or spontaneously dead recipients. During the period of cyclosporin treatment, all implants were free from mononuclear cell infiltrates. At the 10th post-transplantation week, this was still the case for two thirds of the grafts, whereas the others presented only a peripheral infiltration (Fig.3). At all time points numerous insulin-positive cells were present but their individual staining intensity varied (Fig.3). Some aggregates presented foci of cell necrosis (Fig. 3).

In long-term oliguric animals, tissue extraction indicated a negligable pancreatic insulin content and a substantial hepatic insulin store (Table 3). The mean hepatic insulin levels were lower than those measured in recipients without cyclosporin treatment but this observation remains without statistical meaning until more data are available (Table 3 ).

\section{Toxicity of cyclosporin in diabetic $B B$ rats}

The occurrence of spontaneous deaths in the series of cyclosporin-treated transplants led us to examine the effect of the drug on the survival of diabetic controls. Five diabetic $\mathrm{BB}$ rats were kept on insulin injections and re- 

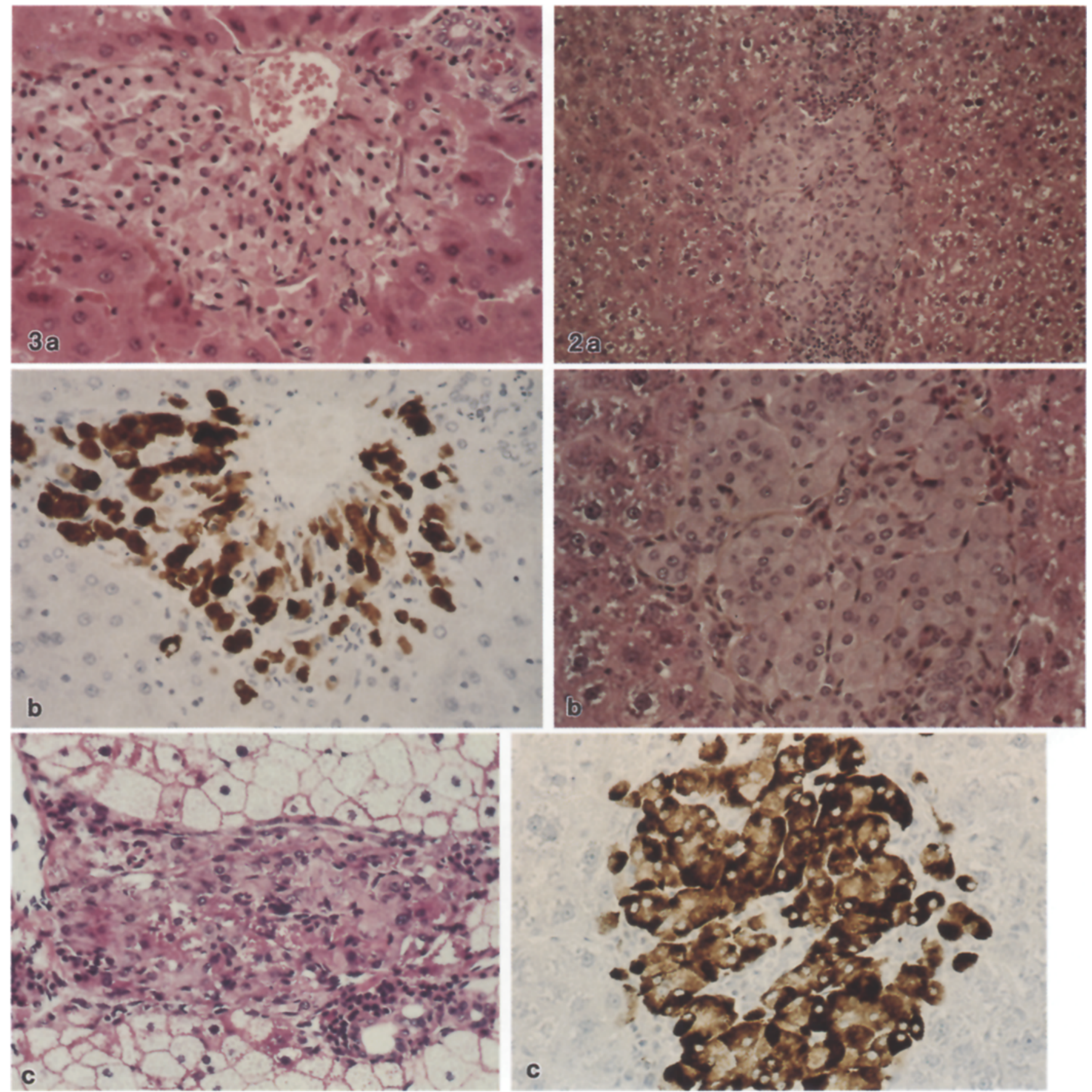

C

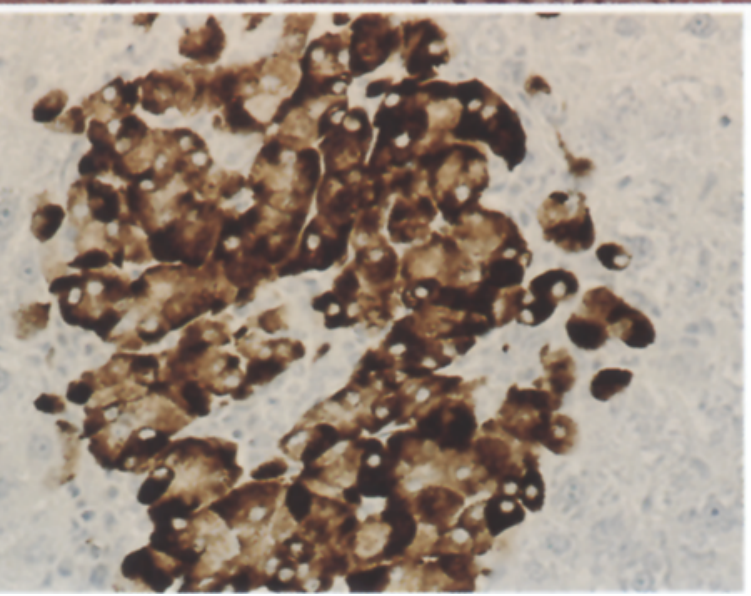

Fig. 2a-c. Light microscopy of intraportal implants consisting of $\mathrm{RT}^{\mathrm{n} / \mathrm{n}}$ purified Beta cells. The analysis was conducted on oliguric BB recipients $\left(\mathrm{RT}^{\mathrm{u} / \mathrm{u}}\right), 10$ weeks after transplantation. Between 20 and $30 \%$ of sectioned implants were infiltrate-free; $40 \%$ exhibited a peripheral infiltration (a HES, $\times 130$ ). The endocrine tissue appeared histologically intact (b HES, $\times 260$ ) and was composed of insulinpositive cells (c immunohistochemistry for insulin $-\times 260$ )

ceived, in addition, a daily oral dose of cyclosporin $5 \mathrm{mg} \cdot \mathrm{kg}^{-1} \cdot \mathrm{day}^{-1}$. All five died between day 18 and day 32 of treatment, whereas none of the 10 diabetic controls without cyclosporin were lost (Table 4). Plasma levels of cyclosporin varied between 50 and $500 \mathrm{ng} / \mathrm{ml}$. Autopsy of the drug-treated BB rats revealed extensive bronchopneumonia and disseminated abcesses, in par-
Fig. 3a-c. Light microscopy of RT1 ${ }^{\mathrm{a} / \mathrm{h}}$ purified Beta-cell grafts in BB recipients which were treated for 5 weeks with cyclosporin. The animals were oliguric at the time of analysis, 10 weeks after implantation. Less than $10 \%$ of sectioned implants presented a diffuse infiltration; other graft sites were not, or only peripherally, infiltrated (a HES $\times 230$ ). Densely stained cells were abundant after immunohistochemistry for insulin $(\mathbf{b} \times 230)$. A few grafts presented signs of focal necrosis $(\mathbf{c}$ HES $\times 230)$

ticular in the kidney; the number of germ centres in the spleen was markedly reduced as compared to untreated controls. The same pathology was observed in cyclosporin-treated transplants which had died spontaneously. The mortality in the latter group was lower (6 of 18) than in the drug-treated diabetic controls ( 5 of 5 ). In the group of transplants without cyclosporin, none of the animals 
Table 4. Effect of cyclosporin on survival of BB rats

\begin{tabular}{lrrr}
\hline Animal group & \multicolumn{4}{c}{ Number of survivors at week } \\
\cline { 2 - 4 } & \multicolumn{1}{c}{5} & 5 & 10 \\
\hline Diabetic BB controls on insulin treatment \\
no Cy & 10 & 10 & 10 \\
$\mathrm{Cy}$ & 5 & 0 & 0 \\
BB recipients of RT1 ${ }^{\text {nth }}$ graft $^{\mathrm{a}}$ & & & \\
no Cy & 22 & 22 & 22 \\
$\mathrm{Cy}$ & 18 & 14 & 12 \\
\hline
\end{tabular}

${ }^{a}$ transplantation carried out on first day of treatment. Cy: cyclosporin A $5 \mathrm{mg} \cdot \mathrm{kg}^{-1} \cdot \mathrm{day}^{-1}$ during first 5 weeks.

died spontaneously during the 10 -week observation period (Table 4).

\section{Discussion}

Diabetic BB rats probably develop their disease as a result of an immune-mediated destruction of their pancreatic Beta cells [6]. This Beta-cell-specific autoreactivity may also interfere with the survival of islet Beta-cell grafts [8], and hence, with the prospects of transplantation as a cure for diabetes with an autoimmune origin. However, if this autoreactivity is MHC-restricted, it may become irrelevant for implants which do not express the RT $1^{\text {u/u }}$ haplotypes that are pathognomic for the BB rat [9]. This possibility can be tested by assessing the survival of $\mathrm{MHC}$ incompatible islet Beta-cell grafts provided they are not rejected by the alloreactivity of the host. Several ways exist to prevent rejection of allogeneic islet tissue in streptozotocin-diabetic rodents: implantation in an immunoprivileged site $[10,11]$, pre-treatment of the donor tissue with the purpose of reducing its immunogenicity $[12,13]$ and immunosuppression of the recipient [14]. Each of these approaches, either alone or in combination, have been applied in diabetic BB rats [15-25]. They have given controversial answers to the question as to whether the allogeneic tissue survives in BB rat hosts or whether it undergoes recurrence of an autoimmune destructive process. The observed discrepancies can be attributed to various explanations, each of which is difficult to experimentally support or exclude. The present study addresses this complex issue in a more simple and standardized experimental model than those which have been used so far. Rat islet Beta cells are purified and reaggregated into particles with documented in vitro $[26,27]$ and in vivo [3] viability and function. The purified Beta-cell aggregates are transplanted in diabetic BB rats and their survival is followed over a 10-week-period. All grafts were prepared from MHC-incompatible donors, with or without disparity in MHC-class I antigens. Similar grafts had been previously found to induce long-term metabolic normalization in syngeneic or allogeneic recipients with streptozotocin-induced diabetes [1-3].

When purified Beta-cell aggregates were prepared from $\mathrm{RT} 1^{\mathrm{n} / \mathrm{h}}$ or RT1 $1^{\mathrm{u} / \mathrm{l}}$ donors, they were capable of correcting the diabetic state in syngeneic streptozotocin-diabetic rats (present study and [3]). The normalized condition was maintained for longer than 20 weeks and the intraportal grafts remained free of mononuclear cell infiltrations during this period [3]. Purified Beta-cell grafts were also successful in allogeneic combinations $\left(\mathrm{RT} 1^{\mathrm{u} / /} \rightarrow \mathrm{RT} 1^{\mathrm{n} / \mathrm{n}}\right)$, in particular when they were composed of a mixture of islet endocrine Beta and non-Beta cells or when their implantation was temporarily covered with cyclosporin $[1,2]$. The allogeneic implants exhibited a mild but persistent infiltration of mononuclear cells which did not become more prominent with time $[1,2]$. We have now examined whether allografts of purified endocrine islet cells can establish a normalization in diabetic BB rats $\left(\mathrm{RT}^{\mathrm{u}}{ }^{\mathrm{u} u}\right)$. The results of this study are compared to those obtained in allografted streptozotocin-diabetic rats.

In an allogeneic combination with MHC-class I homo$\operatorname{logy}\left(\mathrm{RT} 1^{\mathrm{ul}} \rightarrow \mathrm{RT} 1^{\mathrm{u} / \mathrm{u}}\right)$, none of the previously successful conditions induced a long-lasting normoglycaemia in the BB transplants: neither the addition of other islet endocrine cells nor the administration of cyclosporin prevented massive infiltration of the purified Beta-cell grafts and their subsequent destruction. The failure of the $\mathrm{RT} 1^{\mathrm{u} / /}$ Beta-cell grafts in RT1 $1^{\mathrm{u} / \mathrm{l}}$ rats may result from the fact that these recipients generate a stronger alloreactivity towards the donor Beta cells than the previously tested $\mathrm{RT}^{\mathrm{n} / \mathrm{in}}$ strain [1]. Since purified endocrine cell preparations are devoid of MHC-class II expressing cells [3], it is unlikely that the disparity in class II or Ia antigens is responsible for this phenomenon. There is, on the other hand, the possibility that the homology in class I antigens reactivated host $T$ cells to attack donor islet Beta cells via an autoimmune process. Treatment with antibodies against $T$ cell subsets could have assessed this possibility [24]. That cyclosporin did not suppress such autoimmune destruction of the graft may be related to the mode of its administration. The drug was given in a regimen that was shown to suppress alloreactivity towards purified Betacell grafts [2], but that differred markedly from the treatments used to prevent or delay autoimmune destruction of pancreatic Beta cells $[28,29]$. Under the latter conditions, cyclosporin has been shown to prolong survival of pseudoisogenic islet grafts in diabetic BB rats [25].

In the allogeneic combination with a disparity in MHCclass I antigens $\left(R T 1^{1 / n} \rightarrow R T 1^{n / u}\right.$ ), the survival of purified islet Beta-cell grafts was markedly longer than that with class I homology. Ten weeks after transplantation, $30 \%$ of the $\mathrm{BB}$ recipients were still oliguric and normoglycaemic, a percentage which is slightly lower than in similarly treated streptozotocin-diabetic animals [1]. Addition of islet endocrine non-Beta cells to the Beta-cell aggregates increased the success rate, but not to the rate seen in rats with chemically-induced diabetes [1]. We have not yet investigated the reasons for the lower efficacy of the mixed endocrine graft in diabetic BB rats. Possible explanations are a higher immunogenicity of allografted $\mathrm{RT}^{\mathrm{n} / \mathrm{n}}$ islet Beta cells or a lower beneficial effect of the supplemented non-Beta endocrine cells. Other reasons may be strictly metabolic such as the higher body weight of the $\mathrm{BB}$ recipient at the time of transplantation or its lack of any pancreatic insulin reserve. A variation in graft composition and a combination with insulin therapy may clarify some of these issues. 
In further analogy to our previous allograft data (2), a 5-week cyclosporin treatment suppressed the mononuclear cell infiltration of allografts in diabetic BB rats and preserved their function in virtually all recipients, even after discontinuation of the drug. Administration of cyclosporin was, however, markedly less tolerated in diabetic $\mathrm{BB}$ rats, causing death in one third of the $\mathrm{BB}$ transplants; no morbidity was noticed in cyclosporintreated BN transplants or in untreated BB transplants. Although no immunologic analysis was performed, it seems likely that the BB rats - which are already $\mathrm{T}$ cell deficient - developed a severe immunodeficiency upon cyclosporin treatment. This could explain the generalized infection that was found at autopsy. This serious side-effect was not observed in cyclosporin-treated $\mathrm{BN}$ rats [2]; it was unrelated to the implantation, as it was also observed - with even higher mortality $(100 \%)$ - in cyclosporintreated diabetic BB-controls. The diabetic state may thus accelerate the development of a cyclosporin-induced morbidity in BB rats. This could explain why no mortality has been reported for cyclosporin administrations to nondiabetic BB rats $[28,29]$. The mean circulating cyclosporin concentrations in diabetic BB rats were not significantly different from those in streptozotocin-diabetic rats [2], but presented wider fluctuations, sometimes reaching the levels which were found to be cytotoxic for islet cells in vitro [2]. That the drug may have damaged a number of islet Beta cells in vivo is suggested by the lower hepatic insulin content in cyclosporin-treated recipients.

The present experiments indicate that MHC incompatible islet Beta cells can survive in rats with diabetes of autoimmune origin, provided that they are implanted under conditions which allow allograft acceptance. This requirement can be met by composing grafts of purified islet endocrine cells and by covering their implantation by a short-term cyclosporin administration. Treatment with cyclosporin can, however, cause toxic effects in diabetic $\mathrm{BB}$ rats, stressing the need to adjust the dose, route and period of drug therapy in these animals. The use of other immunosuppressive agents, such as antilymphocyte serum, should also be considered. It is concluded that the standardized preparation of islet cell grafts with selected cellular composition can help assessing the conditions for successful transplantation in diabetes with an autoimmune origin. Future studies should examine the immunologic and metabolic status of the purified Beta-cell grafts over longer periods than those covered in the present work. It will be interesting to compare these data with the survival of other tissues in the same donor-recipient combination. These control studies with non-Beta-cell grafts can help distinguish between Beta-cell specific destruction mechanisms and alloreactivity. They will, however, require the use of purified cell grafts in order to make comparison with Beta-cell grafts possible. The availability of purified Alpha-cell preparations [30] could provide a useful control tissue which can be carried through the same preparation and implantation procedures as the Beta-cell grafts.

Acknowledgements. The authors thank Mrs. L. Heylen, Mr. B. Vanbrabandt and Mr. E.Peters for expert technical assistance and Mrs.
N. Van Slycke for excellent secretarial work. This work was supported by grants from the Belgian Ministerie Wetenschapsbeleid (Gekoncerteerde Aktie 86/91-102) and from the Belgian Fonds voor Geneeskundig Wetenschappelijk Onderzoek (3.0059.86 and $3.0075 .88)$

\section{References}

1. Pipeleers D, Pipeleers-Marichal M, Vanbrabandt B, Duys S (1991) Transplantation of purified islet cells in diabetic rats. 2. Immunogenicity of allografted islet B cells. Diabetes (in press)

2. Pipeleers-Marichal M, Ling ZD, Teng H, Pipeleers D (1991) Transplantation of purified islet cells in diabetic rats. 3. Immunosuppressive effect of cyclosporin. Diabetes (in press)

3. Pipeleers D, Pipeleers-Marichal M, Hannaert JC, Berghmans M, In't Veld PA, Rozing J, Van De Winkel M, Gepts W (1991) Transplantation of purified islet cells in diabetic rats. 1.Standardization of islet cell grafts. Diabetes (in press)

4. Sutherland DER, Goetz FC, Najarian JS (1984) Pancreas transplants from related donors. Transplantation 38: 625-633

5. Sibley RK, Sutherland DER, Goetz F, Michael AF (1985) Recurrent diabetes mellitus in the pancreas iso- and allograft. A light and electron microscopic and immunohistochemical analysis of four cases. Laboratory Invest 53: 132-144

6. Like AA, Weringer EJ (1988) Autoimmune diabetes in the BioBreeding/Worcester rat. In: Lefèbvre PJ, Pipeleers DG (eds) The pathology of the endocrine pancreas in diabetes. Springer, Berlin Heidelberg New York, pp 269-284

7. Ball PE, Munzer H, Keller HP, Abisch E, Rosenthaler J (1988) Specific ${ }^{3} \mathrm{H}$ radio-immunoassay with a specific monoclonal antibody for monitoring cyclosporine in blood. Clin Chem 34: 257261

8. Weringer EJ, Like AA (1986) Diabetes mellitus in the BB/W rat: insulitis in pancreatic islet grafts after transplantation in diabetic recipients. Am J Pathol 125: 107-112

9. Colle E, Gutmann RD, Seemayer TA, Michel F (1983) Spontaneous diabetes mellitus syndrome in the rat. IV. Immunogenetic interactions of MHC and non-MHC components of the syndrome. Metabolism 32: 54-61

10. Bobzien B, Yasunami Y, Majercik M, Lacy PE, Davie JM (1983) Intratesticular transplants of islet xenografts (rat to mouse). Diabetes 32: 213-216

11. Tze WJ, Tai J (1986) Intrathecal allotransplantation of pancreatic endocrine cells in diabetic rats. Transplantation 41: 531-534

12. Lacy PE (1988) Perspective of islet cell transplantation in diabetes. In: Lefèbvre PJ, Pipeleers DG (eds) The pathology of the endocrine pancreas in diabetes. Springer, Berlin Heidelberg New York, pp 310-328

13. Lafferty KJ, Gill RJ (1989) Current controversies and new horizons: is there a clinical future for the modulation of donor organ immunogenicity? In: Brent, Cells (eds) Organ transplantation, current clinical and immunological concepts. Bailliere, Tindall, pp 167-175

14. Gray DWR, Morris PJ (1984) Cyclosporine and pancreas transplantation. World J Surg 8: 230-235

15. Selawry H, Fajaco R, Whittington K (1985) Intratesticular islet allografts in the spontaneously diabetic $\mathrm{BB} / \mathrm{W}$ rat. Diabetes 34 : 1019-1024

16. Tze WJ, Tai J (1984) Successful intracerebral allotransplantation of pancreatic endocrine cells in spontaneous diabetic BB rats without immunosuppression. Metabolism 33: 785-789

17. Woehrle MF, Markmann JF, Armstrong J, Naji A (1987) Effect of transplant site on islet allograft survival in BB rats. Transplant Proc 19:925-927

18. Weringer EJ, Like AA (1985) Immune attack on pancreatic islet transplants in the spontaneously diabetic BioBreeding/Worcester $(\mathrm{BB} / \mathrm{W})$ rat is not MHC restricted. J Immunology 134: 2383 2386 
19. Woehrle M, Markmann JF, Silvers WK, Barker CF, Naji A (1986) Transplantation of cultured pancreatic islets to BB rats. Surgery 100: 334-341

20. Prowse SJ, Bellgrau D, Lafferty KJ (1986) Islet allografts are destroyed by disease occurrence in the spontaneously diabetic $\mathrm{BB}$ rat. Diabetes $35: 110-114$

21. Hegre OD, Enriquez AJ, Ketchum RJ, Weinhaus AJ, Serie JR (1989) Islet transplantation in spontaneously diabetic BB/Wor rats. Diabetes 38:1148-1154

22. Chabot JA, Lau H, Reemtsma K, Hardy MA (1986) Long-term survival of islet allografts in spontaneously diabetic BB rats without chronic immunosuppression. Transplant Proc 28: 1851-1853

23. von Specht BU, Dibelius A, Königsberger H, Lodde G, Roth H, Permanetter W (1989) Prolongation of islet and pancreas graft survival in spontaneous diabetic $\mathrm{BB} / \mathrm{W}$ rats by perioperative cyclosporin or 15-deoxyspergualin therapy. Transplant Proc 21: 965-967

24. Jacobson JD, Markmann JF, Brayman KL, Barker CF, Naji A (1988) Prevention of recurrent autoimmune diabetes in BB rats by anti-asialo-GM1 antibody. Diabetes 37: 838-841

25. Königsberger H, Dibelius A, Permanetter W, Walter P, Brendel W, von Specht BU (1987) Influence of postdiabetic onset time and immunosuppressive treatment on islet grafts in the spontaneous diabetic $\mathrm{BB} / \mathrm{W}$ rat. Transplant 44 : $358-362$

26. Pipeleers D, Schuit F, In't Veld P, Maes E, Hooghe-Peters E, Van De Winkel M, Gepts W (1985) Interplay of nutrients and hor- mones in the regulation of insulin release. Endocrinology 117 : 824-833

27. Schuit F, In't Veld P, Gepts W, Pipeleers D (1988) Glucose stimulates proinsulin biosynthesis by a dose-dependent recruitment of pancreatic beta cells. Proc Natl Acad Sci USA 85: 3865-3869

28. Laupacis A, Stiller CR, Gardell C, Keown P, Dupre J, Wallace AC, Thibert P (1983) Cyclosporin prevents diabetes in BB-Wistar rats. Lancet I: $10-12$

29. Like AA, Dirodi V, Thomas S, Guberski DL, Rossini AA (1984) Prevention of diabetes mellitus in the $\mathrm{BB} / \mathrm{W}$ rat with cyclosporin A. Am J Pathol 117:92-97

30. Pipeleers D, In't Veld P, Van De Winkel M, Maes E, Schuit F, Gepts W (1985) A new in vitro model for the study of pancreatic $A$ and B cells. Endocrinology 117:806-816

Received: 17 December 1990

and in revised form: 19 March 1991

Prof. D. Pipeleers

Department of Metabolism and Endocrinology

Vrije Universiteit Brussel

Laarbeeklaan 103

B-1090 Brussels

Belgium 